
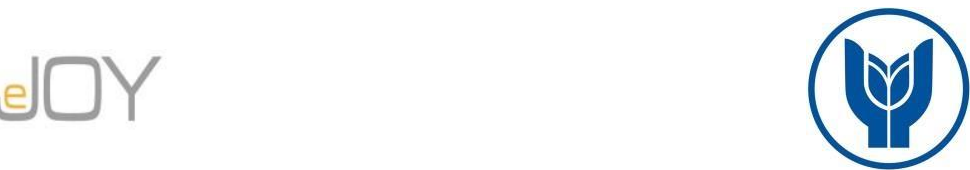

Erkişi, K., Tekin, Ü., E. / Journal of Yasar University, 2019, 14/55, 358-368

\title{
The Relationship Between Intermediate And Capital Goods Imports, Industrial Production And Economic Growth: The Case Of Turkey
}

\author{
Ara malı Ve Sermaye Malı İthalatı, Sanayi Üretimi Ve Ekonomik Büyüme \\ Arasındaki İlişki: Türkiye Örneği
}

\author{
Kemal ERKİȘi, İstanbul Gelişim University, Turkey, kerkisi@gelisim.edu.tr \\ Ümit Engin TEKİN, İstanbul Gelişim University, Turkey, uetekin@ gelisim.edu.tr
}

\begin{abstract}
In this study, the relationship between intermediate goods import $\left(M_{I}\right)$, capital goods imports $\left(M_{C}\right)$, industrial production (IP) and economic growth (GDP) in Turkey was explored by using the quarterly data consist of 32 observations between 2010Q1 - 2017Q4. VAR Granger causality analysis was employed to explore the short-term causality and the direction between variables. It is concluded: a) a bidirectional causality between $G D P$ and $\left.M_{I} b\right)$ a bidirectional causality between $(I P)$ and $\left.\left(M_{I}\right), c\right)$ a unidirectional causality from IP to GDP, $\left.d\right)$ a unidirectional causality from $M_{C}$ to $M_{I}$ and there is not a causality between IP and $M_{C}$. Johansen Co-integration test results indicated a long-term relationship between, $M_{C}, M_{I}$, IP and $G D P$. Variance decomposition was conducted to evaluate the variability of the dependent variable in the process of time. As a result, while in the first period (quarter) GDP is explained by itself at 100\%. However In the tenth period GDP is explained by $18 \%$ GDP, $18 \% M_{C}, 32 \% M_{I}$ and $32 \%$ IP. As a result, increases in $M_{C}$ and IP raise $M_{l}$, or vice versa. IP and $M_{C}$ depend on $M_{I} . M_{I}$ affects GDP both directly and indirectly through IP. The stability of growth both in the short-term and in the long-term depends on imports of intermediate goods in Turkey. Given the chronic foreign trade deficits of Turkey, this pattern of the economy cause to foreign exchange bottlenecks and could have a negative impact on economic stability. In this context, this study supports the claim that liberal policies, which emerged after the 1980s and proposed an export-based growth model, evolved into an importbased growth model in developing countries eventually.
\end{abstract}

Keywords: Economic Growth, Intermediate Goods Imports, Capital Goods Imports, Industrial Production, Turkey.

Öz: Bu çalıșmada, 2010-2017 yılları arasında 32 gözlemden oluşan üçer aylık veriler kullanılarak Türkiye'deki ara malı ithalatı (MI), sermaye malı ithalatı $\left(M_{C}\right)$, sanayi üretimi (IP) ve ekonomik büyüme (GDP) arasındaki ilişkiler incelenmiştir. Değişkenler arasındaki ilişkinin kısa dönemde nedenini ve yönü araştırmak için VAR Granger nedensellik analizi kullanılmıştır. Buna göre: a) GDP ve MI arasında iki yönlü, b) IP ile MI arasında iki yönlü, c) IP'den GDP'ye tek yönlü, d) $M_{C}^{\prime}$ den $M_{I}^{\prime}$ ye tek yönlü bir nedensellik tespit edilirken, IP ve $M_{C}$ arasinda herhangi bir nedensellik bulunmamıştır. Seriler arasında uzun dönemli ilişkinin varlığının tespitinde Johansen Eşbütünleşme testi uygulanmış ve $M_{C}, M_{1}$, IP ve GDP arasında uzun dönemli bir ilişki olduğu tespit edilmiştir. Bă̆ımlı değişkenin zaman içindeki değişkenliğini değerlendirmek için varyans ayrıştırma yöntemi kullanılmıştır. Buna göre ilk çeyrekte GDP'deki değişim \% 100 seviyesinde yine kendisi ile açılanmaktadır. Ancak onuncu çeyrekte iktisadi büyüme, \% 18 GDP, \% 18 MC, $\% 32 M_{I}$ ve \% 32 IP ile açıllanmaktadır. Buna göre, $M_{C}$ ve IP artışlar, $M_{I}$ artırmaktadır. Bunun tersi de doğrudur. IP ve $M_{C}, M_{I}$ ya bağımlıdır. M ekonomik büyümeyi hem doğrudan, hem de IP vasitasıyla dolayll etkilemektedir. Sonuç olarak, kisa ve uzun dönemde büyümenin istikrarl, ara mall ithalatına bağlıdır. Türkiye'nin kronik dış ticaret açı̆̆ı göz önüne alındığında, ekonominin bu yapısl, döviz darboğazlarına yol açarak ekonomik istikrar üzerinde olumsuz etki yaratabilir. Bu bağlamda, bu çalışma, 1980'lerden sonra ortaya çıkan ve ihracata dayalı büyüme modelini öneren liberal politikaların, gelişmekte olan ülkeler için ithalata dayalı büyüme modeli haline geldiği argümanını desteklemektedir.

Anahtar kelimler: İktisadi Büyüme, Aramalı İthalatı, Sermaye Malı İthalatı, Endüstriyel Üretim, Türkiye.

\section{Introduction}

In the developing countries, outward-oriented growth policies gained momentum after 1980. The effects of outwardoriented growth policies on the efficiency of resource allocation, economies of scale and the development of skilled labour are accepted through many studies(Lee, 1995: 1). In this sense, by means of technology transfer, R \& D investments, importation of intermediate and capital goods, the economies of scale are expected to create cost-reduction effects in developing countries. The economies, which are able to compete in the world trade by shifting to economies of scale, expand their product range in exports and imports (Esfahani, 1991: 94).

The impacts of international trade, with its component as importation and exportation, on economic growth are examined in outward-oriented growth theories. It is assumed that a raise in exports will heighten imports that stem from the need for $\mathrm{M}_{\mathrm{I}}$ and $\mathrm{M}_{\mathrm{C}}$ to be used in production and thus will affect the growth positively (Zhang and Zou, 1995: 1; Mody and Y1lmaz, 2002: 24). Considering the critical relationships between savings, investment and net imports, the sources provided from international financial markets may affect the economic growth positively if it is allocated to capital goods importation instead of consumer goods importation (Alfaro and Hammel, 2007: 130).

On the other hand, a raise in growth upraise the foreign trade of intermediate goods and capital goods, thus increase the labour costs and so average costs of entrepreneurs that are produced the same product group. A rising in production costs cause to decreasing in the international competitiveness of the producers, and consequently, growth expectation in the long term effects negatively. Moreover, the growth leads to affect international terms of trade of the technological 
capital goods or intermediate goods and trigger the transition to higher value-added exports (Lee, 1995: 2). When this is not the case, it is thought that the impact of growth on exports and thus imports will be weak. The increase in labour costs will increase the purchasing power of households, thus increasing domestic demand and import of consumer goods. However, if the increase in domestic demand and importation of consumer goods faster than the exports' then it cannot be achieved the desired growth (Solow, 1994: 46).

In Turkey, on January 24, 1980, it is decided to implement an export-oriented growth policy in place of import substitution industrialization policy. To this end, the tariffs and non-tariff barriers in the pre-1980 period were reduced significantly, and the barriers to imports were removed. By the export-oriented growth model, it is aimed to increase the economic growth by enhancing the free market on a global scale. The most important criticism brought to export-oriented growth model is because of the necessary precautionary measures for the acceleration of exports are not fulfilled, export production is achieved only by an increase in importation of capital and intermediate goods. In this context, the exportoriented policies do not provide enhancing of savings and new technology but cause to boost consumer and intermediate goods importation. Since exports cannot grow faster than imports, and when the exports depend on imports, the transition of a country from the final consumer and intermediate goods importer to the intermediate goods and capital goods exporter is delayed (Krauger, 1983: 32; Zhang and Zou, 1995: 5).

Today, neoliberal policies, which are determined as an export-oriented growth model by developing countries, are transformed into import-oriented growth policies. In this study, the relationship between intermediate goods imports ( $\left.\mathrm{M}_{\mathrm{I}}\right)$, capital goods imports $\left(\mathrm{M}_{\mathrm{C}}\right)$, industrial production (IP) and economic growth (GDP) in Turkey was explored by using the quarterly data consist of 32 observations between 2010Q1 - 2017Q4.

After a brief introduction to the theoretical background, the results of the literature review will be summarized. Then, by establishing an econometric model, long and short-term causality and interactions between variables will be investigated. Findings will be summarized in the conclusion section.

\section{Theoretical Framework}

After 1930, economic growth models began to take their place in the economic and mathematical literature. In particular, R. Harrod (1929), F. Ramsey (1928), Schumpeter (1934), P. Samuelson (1947), Swan (1956), R. Solow (1956), E. Domar (1957) conducted studies on topics related to economic growth and capital-labour stock changes by creating apropos models. This progress in macroeconomic models enables us to analyse, plan and estimate the relationships between global economic indicators including national income, labour and production. Macroeconomic growth models illustrate the change in aggregate indicators and produce worthful insights on progress in specific sectors of the economy (Vinnychuk et al., 2015: 37).

Harrod-Domar argues that the relationship between production and savings rates may have a long-term impact on growth. Each economy should transfer a certain proportion of its national income to savings, and the growth rate should be determined after the depreciation of capital goods is deducted. The transformation of savings into investment will increase the demand for production factors, and each supply can create its own demand. The increase in demand for production factors makes the relationship between foreign trade and growth important (Solow, 1994: 47). The most prominent obstacle to economic growth is the comparatively low savings in many underdeveloped or transition economies, and thus new capital formation. In case the effective demand cannot be provided from within the country, intermediate or capital goods are covered by imports. In the long run, the transfer of capital stock obtained from international financial markets through savings to imported intermediate goods and capital goods enables the increase of potential national income (Kim, 2017: 3).

Solow (1956) stated that the increase in capital and labour productivity is due to sustainable exogenous technological increases. Sustainable economic growth will only be possible if exogenous technological development increases the efficiency of labour. (Grossman, 1994: 25). The exogenous effect of technology on labour is the ability to produce higher value-added products that will arise from the individual becoming more qualified. The more qualified the labour, the higher the rate of increase in production. Moreover, direct investments cause to raise in investments in fixed capital and so boost the productivity of the production and therefore more output can be achieved with less input.. Efficiency, which means getting more output by using less input, will also be the cause of economic growth. (Zhang and Zou, 1995: 3). Increasing the productivity of labour and capital in production by means of exogenous technological development will enhance the capital stock and will be able to created saving surplus. The increase in the capital stock in the country will ensure the improvement in production and consequently boost economic growth through technological changes.

The criticisms brought to the studies explaining the process of technological change through exogenous growth models have resulted in new models that internalize the process of technological change since the mid-1980s. Amsden (1989) suggested that the exogenous growth model is not a suitable model for developing countries. According to Amsden (1989), borrowing of foreign technologies through import and transfer does not increase productivity. However, if technological change is internalized, the desired growth level can be reached. (Zhang and Zou, 1995: 4). In the endogenous growth model, Romer (1986) and Lucas (1988) examined the effects of R \& D, technological change, and human capital on economic growth (Teixeira \& Fortuna, 2010: 336). Grossman and Helpman (1991), Rivera-Batiz and Romer (1991) 
emphasized that encouraging technology by decision-makers could increase production through endogenous growth. (Gerni et.al., 2013: 20).

Despite criticism of macroeconomic growth models, the common sense does not change in both exogenous and endogenous growth models; savings, labour, human capital and technological developments through foreign trade provide economic growth. The fact that the relationship between the imports and exports of intermediate goods, investment goods and economic growth makes different results for each country or integration increases the number of studies on these issues. With this respect, the relations between intermediate goods import, capital goods import, industrial production and economic growth will be empirically investigated for the case of Turkey in this article.

\section{Literature Review}

The investigations on causality between the exports, imports and economic growth was summarised in Table1 below.

Table 1. Literature Review

\begin{tabular}{|c|c|c|}
\hline Researcher & Data Span and Method & Findings \\
\hline $\begin{array}{l}\text { Esfahani H. S. } \\
(1991)\end{array}$ & $\begin{array}{l}\text { Ordinary least-squares method } \\
\text { (OLS) 1960-86 } \\
\text { 31 Developing countries }\end{array}$ & $\begin{array}{l}\text { Even though it is concluded a positive impact of } \\
\text { export on growth, it loses its effect due to the } \\
\text { importation of intermediate goods. }\end{array}$ \\
\hline $\begin{array}{l}\text { Zhang, X. \& } \\
\text { Zou, H. } \\
\text { (1995) }\end{array}$ & $\begin{array}{l}\text { Panel data analysis } \\
\text { Regression analysis, } \\
\text { 1965-1988, } \\
\text { 50 developing countries } \\
\end{array}$ & $\begin{array}{l}\text { The relationship between technology transfer and } \\
\text { growth was investigated. It was concluded that in } \\
\text { developing countries, foreign technology transfer had } \\
\text { a positive impact on economic growth. }\end{array}$ \\
\hline $\begin{array}{l}\text { Lee J. W. } \\
(1995)\end{array}$ & $\begin{array}{l}\text { 2SLS method, } \\
\text { Ordinary LS method } \\
\text { 1960- 1988, } 89 \text { OECD } \\
\text { countries. }\end{array}$ & $\begin{array}{l}\text { The relationship between long-term growth and } \\
\text { capital goods import was analysed. It is concluded } \\
\text { that imported capital goods have higher productivity } \\
\text { than the capital goods produced domestically. }\end{array}$ \\
\hline $\begin{array}{l}\text { Wang, J. \& } \\
\text { Xu, B. } \\
(1999)\end{array}$ & $\begin{array}{l}\text { heteroscedasticity consistent } \\
\text { covariance matrix estimator, } \\
\text { 1983-1990, } \\
20 \text { OECD countries }\end{array}$ & $\begin{array}{l}\text { The relationship between capital goods trade and } \mathrm{R} \& \\
\mathrm{D} \text { spreads was explored. As a result, capital goods } \\
\text { trade was effective in transferring information and } \\
\text { increasing the volume of trade. }\end{array}$ \\
\hline $\begin{array}{l}\text { Lawrence, R. Z. } \\
\text { \& Weinstein, D. } \\
\text { E (1999) }\end{array}$ & $\begin{array}{l}\text { Regression analysis, } \\
1964-1985, \\
\text { South Korea }\end{array}$ & $\begin{array}{l}\text { The relationship between total factor productivity, } \\
\text { export and import were investigated. It is concluded a } \\
\text { positive relation in export and total factor } \\
\text { productivity, but this relationship disappear when } \\
\text { importation considered. }\end{array}$ \\
\hline $\begin{array}{l}\text { Eaton , J.\& } \\
\text { Kortum, S. } \\
(2001)\end{array}$ & $\begin{array}{l}\text { Ordinary least-squares method } \\
\text { (OLS), } \\
\text { 1985, } 35 \text { OECD Countries }\end{array}$ & $\begin{array}{l}\text { The relationship between economic growth and } \\
\text { barriers to capital goods was researched. There is a } \\
\text { positive relation between equipment trade and } \\
\text { productivity. }\end{array}$ \\
\hline $\begin{array}{l}\text { Chuang, Y.C. } \\
(2002)\end{array}$ & $\begin{array}{l}\text { Regression analysis, } \\
1960-1985, \\
78 \text { Countries }\end{array}$ & $\begin{array}{l}\text { Relationship between learning through technology } \\
\text { and economic growth was investigated. As a result, } \\
\text { the effect of technology imports on long-term growth } \\
\text { is positive and significant. }\end{array}$ \\
\hline $\begin{array}{l}\text { Mody, A. \& } \\
\text { Yilmaz, K. } \\
(2002)\end{array}$ & $\begin{array}{l}\text { Cobb-Douglas function } \\
\text { F- Statistic test, MacKinnon J, } \\
1967-1990, \\
14 \text { developed and } \\
25 \text { developing countries }\end{array}$ & $\begin{array}{l}\text { The relationship between the import of intermediate } \\
\text { goods and export competition was investigated. It } \\
\text { was concluded that intermediate goods and } \\
\text { machinery imports have a significant cost-cutting } \\
\text { effect in developed countries and export-oriented } \\
\text { economies. }\end{array}$ \\
\hline $\begin{array}{l}\text { Alam, M. I. } \\
(2003)\end{array}$ & $\begin{array}{l}\text { DF, ADF and OLS, } \\
1955-1990 \\
\text { Brasil and Mexico }\end{array}$ & $\begin{array}{l}\text { Capital goods imports have an impact on production. } \\
\text { Capital goods importation cause to increase in } \\
\text { exports. }\end{array}$ \\
\hline $\begin{array}{l}\text { Thangavelu, S. } \\
\text { M.\& Rajaguru, } \\
\text { G. (2004) }\end{array}$ & $\begin{array}{l}\text { VAR Analysis, } \\
1960-1996 \\
9 \text { Asian Countries }\end{array}$ & $\begin{array}{l}\text { The relationship between export, import and } \\
\text { productivity was investigated. It is concluded that } \\
\text { exports and imports have equal effects in an open } \\
\text { economy. }\end{array}$ \\
\hline $\begin{array}{l}\text { Bade, } \mathrm{M} \text {. } \\
(2005)\end{array}$ & $\begin{array}{l}\text { Johansen Cointegration } \\
\text { Variance Decomposition and } \\
\text { the Impulse Responses }\end{array}$ & $\begin{array}{l}\text { Capital and intermediate goods importation affect } \\
\text { growth through technology transferring. }\end{array}$ \\
\hline
\end{tabular}




\begin{tabular}{|c|c|c|}
\hline & 1980-2003, Jordan & \\
\hline $\begin{array}{l}\text { Alfaro, L. \& } \\
\text { Hammel, E. } \\
(2006)\end{array}$ & $\begin{array}{l}\text { Regression analysis, } \\
1980-1997, \\
12 \text { selected countries }\end{array}$ & $\begin{array}{l}\text { The relationship between stock market liberalization } \\
\text { and capital goods imports was analysed. As a result, } \\
\text { the liberalization of the stock market increases the } \\
\text { capital goods trade. }\end{array}$ \\
\hline $\begin{array}{l}\text { Türkcan, K. } \\
(2007)\end{array}$ & $\begin{array}{l}\text { Levin-Lin-Chu (LLC) panel } \\
\text { data analysis, } \\
\text { 1989-2003, } \\
25 \text { OECD +USA }\end{array}$ & $\begin{array}{l}\text { There is a positive relation between intermediate } \\
\text { goods exports and foreign direct investments. }\end{array}$ \\
\hline $\begin{array}{l}\text { Kasahara ,H. \& } \\
\text { Rodrigue J. } \\
\text { (2007) }\end{array}$ & $\begin{array}{l}\text { Least-squares method, } \\
\text { 1979-1996, } \\
\text { Chile }\end{array}$ & $\begin{array}{l}\mathrm{M}_{\mathrm{I}} \text { affects company productivity was investigated. It } \\
\text { was determined that imports of intermediate goods } \\
\text { increased the company efficiency by } 2.6 \text { percent. }\end{array}$ \\
\hline $\begin{array}{l}\text { Awokuse, T.O. } \\
\text { (2008) }\end{array}$ & $\begin{array}{l}\text { Var - Granger Causality } \\
\text { Analysis, } \\
\text { 1993-2002, } \\
\text { Argentina, Colombia and Peru }\end{array}$ & $\begin{array}{l}\text { It is concluded that import and export affect } \\
\text { economic growth positively. The effect of } \\
\text { importation is as high as exports. }\end{array}$ \\
\hline $\begin{array}{l}\text { Miroudot , S. } \\
\text { Lanz, R. } \\
\text { Ragoussis, A. } \\
\text { (2009 }\end{array}$ & $\begin{array}{l}\text { 2SLS, OLS } \\
1990-2005 \\
20 \text { OECD Countries }\end{array}$ & $\begin{array}{l}\text { Intermediary goods and services trade between } \\
\text { OECD countries was examined. Intermediate goods } \\
\text { trade affects economic growth. }\end{array}$ \\
\hline $\begin{array}{l}\text { Teixeira, A. \& } \\
\text { Fortuna, N. } \\
(2010)\end{array}$ & $\begin{array}{l}\text { ADF -PP Test, Cointegration } \\
\text { Analysis, 1960-2001, Portugal }\end{array}$ & $\begin{array}{l}\text { It is concluded that capital goods imports contribute } \\
\text { to economic growth more than domestic R \& D } \\
\text { investments. }\end{array}$ \\
\hline $\begin{array}{l}\text { Bas, M. \& } \\
\text { Berthou, A. } \\
(2012)\end{array}$ & $\begin{array}{l}\text { Levinsohn-Petrin } \\
\text { methodology, } \\
\text { 1997-2006, } \\
\text { India, }\end{array}$ & $\begin{array}{l}\text { The impact of financial records of firms on the } \\
\text { decision to fund capital goods. It is concluded that } \\
\text { firms that provide financial recovery have a high } \\
\text { probability of upgrading foreign technology. }\end{array}$ \\
\hline $\begin{array}{l}\text { Gerni, C. et al. } \\
(2016)\end{array}$ & $\begin{array}{l}\text { Augmented Dickey- } \\
\text { FullerToda-Yamamoto } \\
\text { Causality Test, } \\
\text { 1980-2007,Turkey }\end{array}$ & $\begin{array}{l}\text { A Unidirectional relationship between exports and } \\
\text { intermediate goods importation is determined. } \\
\text { Investment and intermediate goods importation affect } \\
\text { economic growth. }\end{array}$ \\
\hline $\begin{array}{l}\text { Kandilov , I. T. et } \\
\text { al. (2017) }\end{array}$ & $\begin{array}{l}\text { Panel Data Analysis } \\
\text { 1989-1997, } \\
\text { India }\end{array}$ & $\begin{array}{l}\text { The relationship between international liberalization } \\
\text { and foreign investment goods is examined. A tariff } \\
\text { reduction on investment goods imports positively } \\
\text { affects the imports of investment goods. }\end{array}$ \\
\hline $\begin{array}{l}\text { Kim, H. } \\
(2017)\end{array}$ & $\begin{array}{l}\text { Logistic regression analysis, } \\
\text { 2012-2016, } \\
52 \text { Countries, }\end{array}$ & $\begin{array}{l}\text { A raise in consumer goods causes increase in } \\
\text { importation of capital goods and intermediate goods. }\end{array}$ \\
\hline
\end{tabular}

In the next section, it will be examined the relationship between intermediate goods imports, capital goods imports, industrial production and economic growth.

\section{Econometric Analysis}

\subsection{Variables, Data Set, Model and Methodology}

The data set consist of 32 observations between 2010Q1-2017Q4 for capital goods imports $\left(\mathrm{M}_{\mathrm{C}}\right)$, intermediate goods imports $\left(\mathrm{M}_{\mathrm{I}}\right)$, industrial production (IP) and economic growth (GDP) of Turkey and was compiled the web base statistical sources of Turkish Statistical Institute and Monthly Economic Indicators Report 2018 issued by Ministry of Treasury and Finance of Republic of Turkey.

The functional expression of the model shows the relations between $\mathrm{M}_{\mathrm{C}}, \mathrm{M}_{\mathrm{I}}$, IP and GDP can be described as follows. Growth $=f($ Import Capital Goods, Import Intermediate Goods, Industrial Production) (1)

$$
\supset P=f\left(M_{K}, M_{I}, I P\right)
$$

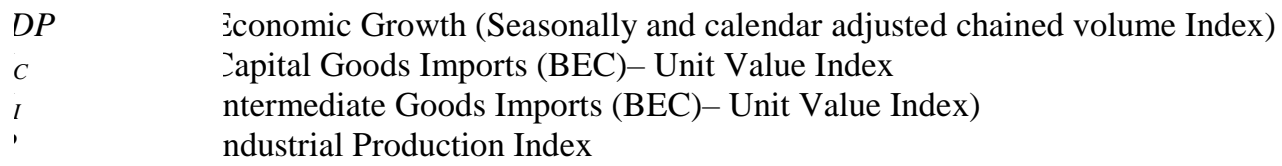

The model in Equation (2) was converted to the econometric model as in Equation (3) to carry on econometric analysis. $G D P_{i t}=a+\beta_{1} M_{C_{t}}+\beta_{2} M_{I}+\beta_{3} I P_{t}+u_{t}$ 
In Equation (3), $a$ represents the fixed term, $\beta$ is the coefficients that define the relations between the GDP, which is the predicted variable and $\mathrm{M}_{\mathrm{C}}, \mathrm{M}_{\mathrm{I}}, \mathrm{I}_{\mathrm{P}}$, which are the predictor variables. $u_{t}$ symbolised the error term.

However, Equation (3) is a static model. By taking the delayed values of the series (i) into the system, the dynamic equations are described in the VAR system as follows.

$d G D P_{t}=a_{11}+\sum_{i=0}^{n} \beta_{1 i} d M_{K_{t-i}}+\sum_{i=0}^{n} \beta_{2 i} d M_{C_{t-i}}+\sum_{i=0}^{n} \beta_{3 i} d I P_{t-i}+\sum_{i=0}^{n} \beta_{4 i} d G D P_{t-i}+u_{1 t}$
$d M_{K_{t}}=a_{21}+\sum_{i=0}^{n} \beta_{5 i} d G D P_{t-i}+\sum_{i=0}^{n} \beta_{6 i} d M_{C_{t-i}}+\sum_{i=0}^{n} \beta_{7 i} d I P_{t-i}+\sum_{i=0}^{n} \beta_{8 i} d M_{K_{t-i}}+u_{2 t}$
$d M_{I t}=a_{31}+\sum_{i=0}^{n} \beta_{9 i} d G D P_{t-i}+\sum_{i=0}^{n} \beta_{10 i} d M_{K_{t-i}}+\sum_{i=0}^{n} \beta_{11 i} d I P_{t-i}+\sum_{i=0}^{n} \beta_{12 i} d M_{I t-i}+u_{3 t}$
(6)
$d I P_{t}=a_{41}+\sum_{i=0}^{n} \beta_{13 i} d G D P_{t-i}+\sum_{i=0}^{n} \beta_{14 i} d M_{K_{t-i}}+\sum_{i=0}^{n} \beta_{15 i} d M_{I-i}+\sum_{i=0}^{n} \beta_{16 i} d I P_{t-i}+u_{4 t}$

Where $d$ displays the first difference, $u_{1}, u_{2}$ and $u_{3}$ shows the error terms and $\mathrm{n}$ is the number of lag-lengths.

In the following title, the regression equation will be established, and the significance of the variables and the model will be tested. Analysis can produce incorrect results when the series is not stationary. Therefore, the stationaries of the series will be examined to reveal if they are significant. Then, Johansen Cointegration Analysis will be implemented to test the long-term relationship between variables. Granger Causality Analysis will be employed to reveal the short-term causality between variables. Variance decomposition method will be employed to analyse how the independent variables affect the dependent variable over time.

\subsection{Application and Findings}

To reveal the significance of the series and the model, Equation (3) was tested with the E-views 8.0 by using the LS Least Squares (NLS and ARMA) method and the results are presented in Table 2.

In the model, GDP the dependent variable represents economic growth. Independent variables are $\mathrm{M}_{\mathrm{C}}$ the capital goods imports, $\mathrm{M}_{\mathrm{I}}$ the intermediate goods imports and IP the industrial production.

Table 2. Model Statistics

\begin{tabular}{lllll}
\hline \hline \multicolumn{4}{c}{$G D P_{i t}=a+\beta_{1} M_{K_{i t}}+\beta_{2} M_{I i t}+\beta_{3} I P_{i t}+u_{i t}$} \\
\hline Variable & Coefficient & Std. Error & t-Statistic & Prob. \\
\hline \hline $\mathrm{M}_{\mathrm{C}}$ & 0.311952 & 0.112758 & 2.766552 & $0.0101^{*}$ \\
$\mathrm{IP}$ & 0.010478 & 0.000205 & 51.02063 & $0.0000^{*}$ \\
$\mathrm{M}_{\mathrm{I}}$ & -0.001189 & 0.000568 & -2.093500 & $0.0458^{* *}$ \\
$\mathrm{C}$ & 2.523749 & 0.519998 & 4.853384 & $0.0000^{*}$ \\
\hline \hline R-squared & 0.990845 & Mean dependent var. & 4.938381 \\
Adjusted R-squared & 0.989828 & S.D. dependent var. & 0.135669 \\
S.E. of regression. & 0.013683 & Akaike info criterion. & -5.625385 \\
Sum squared resid. & 0.005055 & Schwarz criterion. & -5.440355 \\
Log likelihood. & 91.19347 & Hannan-Quinn criteria. & -5.565070 \\
F-statistic & 974.0731 & Durbin-Watson stat. & 0.633712 \\
Prob(F-statistic) & 0.000000 & & & \\
\hline
\end{tabular}

Note: $*$ and $*$ * show that coefficients are statistically significant at the $1 \%$ and $5 \%$ level of significance.

When the probability values of the series are examined in Table 2, it is seen that all the series are significant because of the probability values of $M_{C}, M_{I}$, IP, and $(C)$ are lower than the significance level at 0,05 . The value of $R^{2}$ and Adjusted $\mathrm{R}^{2}$ are remarkably high around 0,99 level. The value of Prob (F-statistic) is equal to 0 and so lower than 0.05 . By taking these results, it can be said that the model is significant.

However, even though $\mathrm{R}^{2}$ values high at 0,99 and the values of f-statistics and t-statistics are below than its confidence limit, there is a still spurious regression risk. Therefore, stationary of the error terms will be tested. The fact that the error terms are stationary at the level indicates that there is no spurious regression.

Table 3. Residual Series Test Results

\begin{tabular}{|c|c|c|l|c|c|}
\hline \multirow{2}{*}{$\begin{array}{l}\mathrm{H}_{0}: \\
\text { Residual has a unit root }\end{array}$} & \multicolumn{2}{|c|}{ Intercept } & \multicolumn{2}{|c|}{$\mathrm{H}_{0}:$} & \multicolumn{2}{c|}{ Trend \& Intercept } \\
\cline { 2 - 3 } \cline { 5 - 6 } & $\mathrm{t}-$ Stat & Prob.(1) & Residual has a unit root & t-Stat & Prob. (1) \\
\hline ADF test statistic & -3.798568 & $0.0077^{*}$ & ADF test statistic & -3.661395 & $0.0424 * *$ \\
\hline \hline Test critical values 1\% & -3.689194 & Test critical values 1\% & -4.323979 \\
\hline $5 \%$ & -2.971853 & $5 \%$ & -3.580623 \\
\hline $10 \%$ & -2.625121 & $10 \%$ & -3.225334 \\
\hline
\end{tabular}

Note: *MacKinnon (1996) one-sided p-values. Exogenous: Constant, Linear Trend. Lag Length: 5 (Automatic - based on SIC, maxlag=5) 
As it is seen in Table 3, the probability value of intercept is 0,0077 and significantly lower than 0,05 . The values of ADF $\mathrm{t}$-statistics are smaller than all the critical values of intercept. Similarly, the probability of trend \& intercept is 0,0424 and lower than 0,05. The ADF t-statistic value is smaller than $-3,580623$ the critical test value at 0,05 . Therefore, the hypothesis of $\mathrm{H}_{0}$, which represents residual has a unit root, is rejected and the alternative hypothesis, which represents residual has no unit root, is accepted. As a result, there is no spurious regression.

To robust the significance of the series and the model, additionally Variance Inflation Factors (VIF), Histogram Normality will be examined. In this context, when Table 4 which shows the VIF Test results is scaned, it is seen that the values of the Centered VIF of the relevant series are between 1,07-1,14 and significantly lower than 5 . If these values are between $1-5$, this indicates that there in not a multicollinearity that means multiple linear relations between depended variables.

Table 4. Variance Inflation Factor

\begin{tabular}{cccc}
\hline \hline Variable & $\begin{array}{c}\text { Coefficient } \\
\text { Variance }\end{array}$ & $\begin{array}{c}\text { Uncentered } \\
\text { VIF }\end{array}$ & $\begin{array}{c}\text { Centred } \\
\text { VIF }\end{array}$ \\
\hline \hline $\mathrm{M}_{\mathrm{C}}$ & 0.012714 & 45164.47 & 1.133921 \\
$\mathrm{IP}$ & $4.22 \mathrm{E}-08$ & 60.82432 & 1.071974 \\
$\mathrm{M}_{\mathrm{I}}$ & $3.23 \mathrm{E}-07$ & 1.157241 & 1.147940 \\
$\mathrm{C}$ & 0.270398 & 44770.38 & $\mathrm{NA}$ \\
\hline \hline
\end{tabular}

The results of Histogram Normality Test seen in Graph 1 show that the probability value of Jarque-Bera is higher than 0.05. This result indicates that there is not multicollinearity in the model and therefore the model is statistically significant.
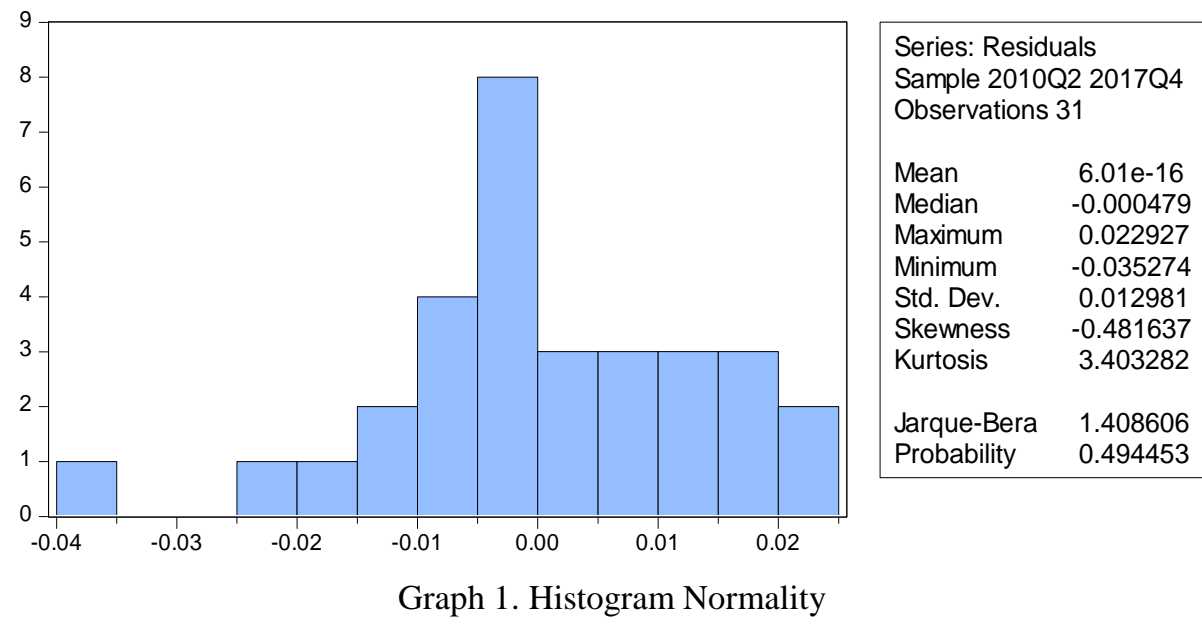

\subsubsection{Unit Root Test}

The most common method used to measure the stationarity of series, or in other words, the degree of integration of series is unit root test. For this purpose, ADF Unit Root Test was employed and the result of the test is summarized in Table 5 .

Table 5 covers the probability and the unit root $t$-statistic values of intercept and trend \& intercept of the series at the level and in first difference. By taking the probability values of the series, it is decided whether the series has a unit root and therefore are stationary or not. If the probability value calculated is less than 0.05 , this indicates that the series does not have a unit root and therefore is stationary.

Table 5. ADF - Unit Root Test Results

\begin{tabular}{|l|l|l|l|l|l|l|l|l|}
\hline & \multicolumn{4}{|l|}{ Level } & \multicolumn{2}{l|}{ First Difference } \\
\cline { 2 - 9 } & Intercept & \multicolumn{2}{l|}{ Trend \& Intercept } & \multicolumn{2}{l|}{ Intercept } & \multicolumn{2}{l|}{ Trend\&Intercept } \\
\hline & $\begin{array}{l}\text { ADF t- } \\
\text { Stat. }\end{array}$ & Prob.(1) & $\begin{array}{l}\text { ADF t- } \\
\text { Stat }\end{array}$ & Prob.(1) & $\begin{array}{l}\text { ADF t- } \\
\text { Stat }\end{array}$ & Prob.(1) & $\begin{array}{l}\text { ADF t- } \\
\text { Stat }\end{array}$ & Prob.(1) \\
\hline GDP & -0.470857 & 0.8840 & -3.204797 & 0.1020 & -6.994840 & $0.0000^{*}$ & -6.873456 & $0.0000^{*}$ \\
\hline $\mathrm{M}_{\mathrm{C}}$ & -2.776469 & 0.0750 & -2.033989 & 0.5574 & -7.597082 & $0.0000^{*}$ & -7.635941 & $0.0000^{*}$ \\
\hline $\mathrm{M}_{\mathrm{I}}$ & -0.474340 & 0.8833 & -2.193539 & 0.4764 & -3.956616 & $0.0049^{*}$ & -4.043659 & $0.0179^{* *}$ \\
\hline SUE & 1.336695 & 0.9980 & -2.190064 & 0.4734 & -3.840269 & $0.0074^{*}$ & -5.599377 & $0.0007^{*}$ \\
\hline
\end{tabular}

Note: $*$ and $* *$ show that coefficients are statistically significant at the $1 \%$ and $5 \%$ level of significance.

(1) MacKinnon (1996) one-sided p-values. 
When the ADF test results are examined in Table 5, it is seen that probability values at the level of all the series for intercept and trend \& intercept are significantly higher than 0,05. This indicates that series have unit roots and therefore are not stationary at level. Once the first order differences are taken, it is seen that the probability values of the series are significantly lower than 0,05 . This indicates that series belong to $\mathrm{M}_{\mathrm{C}} \mathrm{M}_{\mathrm{I}} \mathrm{SUE}$ and GDP are stationary at the first difference. If all the series are I(1), this is considered that series could be cointegrated and therefore in the next title, Johansen Cointegration test will be employed to reveal whether the series are cointegrated.

\subsubsection{Cointegration Analysis}

If two non-stationary time series are equally integrated, then there may be a cointegration between the two series and therefore a long-term relationship. In this context, the co-integration analysis is performed to verify long-run relations between the series.

In Table 5 under the previous title, the stationary of the series was examined, and it was observed that they were stationary at the first order. Then the appropriate lag-length number is determined for the series stationary at the same order. In order to determine the lag-length number, VAR model is established first. According to the information criteria, as given in Table 6, the appropriate lag-length number is decided.

Table 6. VAR Lag Order Selection Criteria

\begin{tabular}{ccccccc}
\hline \hline Lag & LogL & LR & FPE & AIC & SC & HQ \\
\hline \hline 0 & 162.9251 & NA* & $5.77 \mathrm{e}-11$ & -12.22500 & -12.03145 & -12.16927 \\
1 & 172.3241 & 15.18312 & $9.77 \mathrm{e}-11$ & -11.71724 & -10.74947 & -11.43856 \\
2 & 188.7740 & 21.51139 & $1.04 \mathrm{e}-10$ & -11.75185 & -10.00987 & -11.25022 \\
3 & 207.1095 & 18.33545 & $1.15 \mathrm{e}-10$ & -11.93150 & -9.415304 & -11.20692 \\
4 & 235.1110 & 19.38568 & $8.56 \mathrm{e}-11$ & -12.85469 & -9.564286 & -11.90717 \\
$\mathbf{5}$ & $\mathbf{3 0 0 . 9 6 1 5}$ & $\mathbf{2 5 . 3 2 7 1 2}$ & $\mathbf{8 . 1 0 e}-12 *$ & $\mathbf{- 1 6 . 6 8 9 3 5 *}$ & $\mathbf{- 1 2 . 6 2 4 7 3 *}$ & $\mathbf{- 1 5 . 5 1 8 8 8 *}$ \\
\hline \hline
\end{tabular}

Note: * indicates lag order selected by the criterion

LR: sequentially modified LR test statistic (each test at 5\% level); FPE: Final prediction error; AIC: Akaike information criterion; SC: Schwarz information criterion; HQ: Hannan-Quinn information criterion

According to Table 6, 4/5 of information criterions (FPE, AIC, SC, HQ) predicted that the appropriate lag-length for the VAR model is five.

Table 7. Johansen Co-integration Test

A-Unrestricted Cointegration Rank Test (Trace)

\begin{tabular}{ccccc}
\hline \hline $\begin{array}{c}\text { Hypothesized } \\
\text { No. of CE(s) }\end{array}$ & Eigenvalue & $\begin{array}{c}\text { Trace } \\
\text { Statistic }\end{array}$ & $\begin{array}{c}0.05 \\
\text { Critical Valı }\end{array}$ & Prob.** \\
\hline \hline None * & 0.647926 & 72.12534 & 47.85613 & 0.0001 \\
At most 1* & 0.514173 & 41.85183 & 29.79707 & 0.0013 \\
At most 2* & 0.404992 & 20.91663 & 15.49471 & 0.0069 \\
At most 3* & 0.182972 & 5.860371 & 3.841466 & 0.0155 \\
\hline \hline
\end{tabular}

B-Unrestricted Cointegration Rank Test (Maximum Eigenvalue)

\begin{tabular}{ccccc}
\hline \hline $\begin{array}{c}\text { Hypothesized } \\
\text { No. of CE(s) }\end{array}$ & Eigenvalue & $\begin{array}{c}\text { Max-Eigen } \\
\text { Statistic }\end{array}$ & $\begin{array}{c}0.05 \\
\text { Critical Valı }\end{array}$ & Prob.** \\
\hline \hline None * & 0.647926 & 30.27352 & 27.58434 & 0.0220 \\
At most 1 & 0.514173 & 20.93520 & 21.13162 & 0.0532 \\
At most 2* & 0.404992 & 15.05626 & 14.26460 & 0.0374 \\
At most 3* & 0.182972 & 5.860371 & 3.841466 & 0.0155 \\
\hline \hline
\end{tabular}

Trace test indicates 4 cointegrating eqn(s) at the 0.05 level. Max-eigenvalue test indicates 1 cointegrating eqn(s) at the 0.05 level. * denotes rejection of the hypothesis at the 0.05 level. **MacKinnon-Haug-Michelis (1999) p-values

Table 7 shows the results of Johansen co-integration test that was performed to determine a long-term relationship between the series. Based on the test results of Trace unrestricted cointegration rank, all of the values of trace test statistics are higher than their critical values at 0.05 . This result indicates four cointegrating equations. 
The results of the maximum eigenvalue unrestricted cointegration rank test revealed that all the maximum eigenvalue test statistic values, except at most 1 are higher than their critical values at 0.05 . This result indicates one cointegrating equation at the 0.05 level.

Based on both results of trace and Maximum Eigenvalue, it is concluded, a co-integrated vector between the variables and therefore there is a long-run relationship between economic growth, capital goods importation, intermediate goods importation and industrial production.

\subsubsection{VAR Granger Causality Analysis}

Granger causality analysis was performed to investigate the causality and direction between variables in the short term. According to the VAR Granger Causality results seen in Table 8, in Model 1, where GPD is the dependent variable and $\mathrm{M}_{\mathrm{C}}, \mathrm{M}_{\mathrm{I}}$, and IP are independent variables, the probability values of both $\mathrm{M}_{\mathrm{I}}$ and IP are less than 0.05 , but in contrast of that $\mathrm{M}_{\mathrm{C}}$ is greater than 0.05 . Accordingly, $\mathrm{M}_{\mathrm{I}}$ and IP are the granger cause of GDP. In Model II, where $\mathrm{M}_{\mathrm{C}}$ is the dependent variable, the probability values of all independent variables are considerably above 0.05 .

For this reason, GDP, $M_{I}$ and IP are not the granger cause of $M_{C}$. In model III, where the $M_{I}$ is the dependent variable, the probability values of GDP, MC and IP series are below 0.05. Therefore, GDP, MC and IP are the causes of $\mathrm{M}_{\mathrm{I}}$. In Model IV, where IP the industrial production is the dependent variable, the probability value of MI is less than 0.05 , and it is the granger cause of the industrial production.

Table 8. VAR Granger Causality Test

\begin{tabular}{llll||lclc}
\multicolumn{5}{l|}{ Model I - Dependent variable: $d$ GDP } & \multicolumn{4}{l|}{ Model II - Dependent variable: $d \mathrm{M}_{\mathrm{C}}$} \\
\hline \hline Excluded & Chi-sq & $\mathrm{df}$ & Prob. & Excluded & Chi-sq & $\mathrm{df}$ & Prob. \\
$d \mathrm{M}_{\mathrm{C}}$ & 10.25349 & 5 & 0.0684 & $d \mathrm{GDP}$ & 4.388654 & 5 & 0.4949 \\
$d \mathrm{M}_{\mathrm{I}}$ & 57.81052 & 5 & $0.0000^{*}$ & $d \mathrm{M}_{\mathrm{I}}$ & 3.399603 & 5 & 0.6386 \\
$d \mathrm{IP}$ & 25.13477 & 5 & $0.0001^{*}$ & $d \mathrm{IP}$ & 4.493435 & 5 & 0.4808 \\
All & 90.49809 & 15 & $0.0000^{*}$ & All & 9.037384 & 15 & 0.8756 \\
\hline \hline
\end{tabular}

\begin{tabular}{|c|c|c|c|c|c|c|c|}
\hline \multicolumn{4}{|c|}{ Model III - Dependent variable: $d \mathrm{M}_{\mathrm{I}}$} & \multicolumn{4}{|c|}{ Model IV - Dependent variable: $d$ IP } \\
\hline Excluded & Chi-sq & df & Prob. & Excluded & Chi-sq & df & Prob. \\
\hline$d \mathrm{GDP}$ & 12.26750 & 5 & $0.0313 * *$ & $d \mathrm{GDP}$ & 10.09045 & 5 & 0.0727 \\
\hline$d \mathrm{M}_{\mathrm{C}}$ & 13.21167 & 5 & $0.0215 * *$ & $d \mathrm{M}_{\mathrm{C}}$ & 4.940814 & 5 & 0.4231 \\
\hline$d \mathrm{IP}$ & 12.68882 & 5 & $0.0265 * *$ & $d \mathrm{M}_{\mathrm{I}}$ & 23.42309 & 5 & $0.0003 *$ \\
\hline All & 25.29573 & 15 & $0.0461 * *$ & All & 36.87419 & 15 & $0.0013 * *$ \\
\hline
\end{tabular}

Note: $*$ and $* *$ show that coefficients are statistically significant at the $1 \%$ and $5 \%$ level of significance.

The causality between the variables can be depicted as in Table 9 and summarized as follows. There is;

a) a bidirectional causality between economic growth and intermediate goods importation,

b) a bidirectional causality between industrial production and intermediate goods importation

c) a unidirectional causality from industrial production to economic growth

d) a unidirectional causality from capital goods importation to intermediate goods importation.

e) no causality between industrial production and capital goods importation.

f) no causality between economic growth and capital goods importation

Table 9. Short-term Relationships Between the Variables

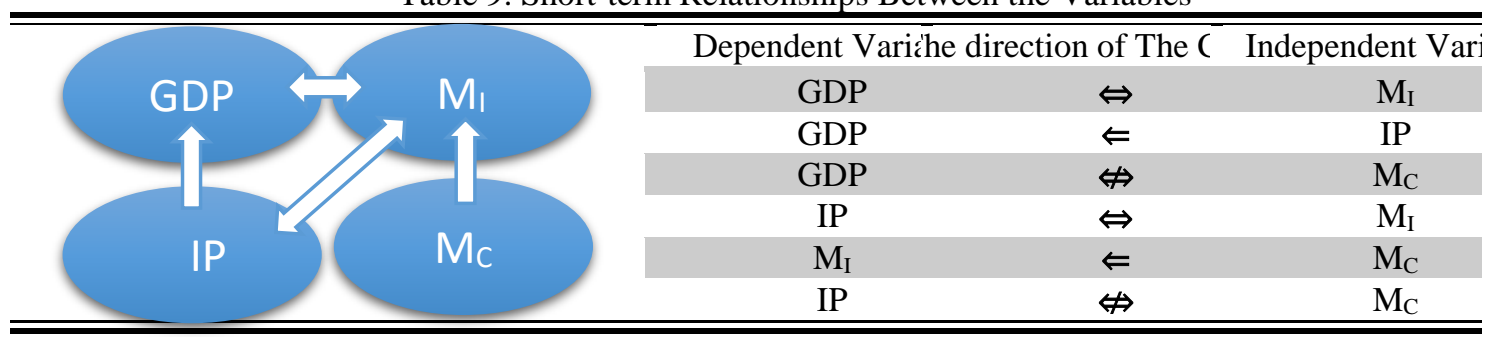

\subsubsection{Variance Decomposition Analysis}

The VAR decomposition shows the ratio between the variations of one variable due to its own shocks and the changes due to shocks of the other variables (Sevüktekin and Çinar, 2014: 515). Therefore, it helps to assess which independent variable explains the variability of the dependent variable over time. 
Erkişi, K., Tekin, Ü., E. / Journal of Yasar University, 2019, 14/55, 358-368

Table 10. Variance Decomposition of GDP

\begin{tabular}{cccccc}
\hline \hline Period & S.E. & $d$ GDP & $d \mathrm{M}_{\mathrm{C}}$ & $d \mathrm{M}_{\mathrm{I}}$ & $d \mathrm{IP}$ \\
\hline \hline 1 & 0.862070 & 100.0000 & 0.000000 & 0.000000 & 0.000000 \\
2 & 1.120584 & 75.26186 & 0.429468 & 18.16178 & 6.146891 \\
3 & 2.502998 & 29.30998 & 26.23020 & 27.18248 & 17.27734 \\
4 & 3.022238 & 20.10970 & 21.99288 & 30.18929 & 27.70812 \\
5 & 3.472029 & 19.01427 & 17.72831 & 30.36637 & 32.89105 \\
6 & 3.581753 & 20.55708 & 19.84988 & 28.60774 & 30.98530 \\
7 & 3.629091 & 22.28987 & 19.65270 & 27.87241 & 30.18502 \\
8 & 3.934657 & 19.77934 & 19.78967 & 31.39271 & 29.03828 \\
9 & 4.065159 & 18.65136 & 18.90489 & 32.96891 & 29.47483 \\
10 & 4.290566 & 18.15921 & 18.16253 & 31.64253 & 32.03572 \\
\hline \hline
\end{tabular}

Cholesky Ordering: $d \mathrm{GDP} d \mathrm{M}_{\mathrm{C}} d \mathrm{M}_{\mathrm{I}} d \mathrm{IP}$

The results of the Variance Decomposition of GDP for ten periods are presented in Table 10. Accordingly, in the first period (quarter) GDP growth is explained by itself at 100\%. In the second period economic growth is explained by $75 \%$ GDP, by $18 \%$ intermediate goods importation and by $6 \%$ industrial production. In the fourth period, GDP growth stems from $20 \%$ GDP, $22 \%$ of capital goods importation, $30 \%$ intermediate goods importation and $27 \%$ industrial production. In the tenth period, economic growth is explained by $18 \% \mathrm{GDP}, 18 \%$ capital goods importation, $32 \%$ intermediate goods importation and $32 \%$ industrial production.

\section{Conclusion}

Although the impact of import and export on economic growth has been widely studied in the literature, it is observed that there are very few studies that measure the impact of imports on growth or industrial production based on commodity groups. In this context, this study contributes to empirical literature.

In this study, the relationship between intermediate and capital goods imports, industrial production and economic growth in Turkey was explored by using the quarterly data consist of 32 observations between 2010Q1 - 2017Q4.

The empirical investigation was initiated with defining regression equation in which economic growth (GDP) was determined as dependent variables and intermediate goods imports $\left(\mathrm{M}_{\mathrm{I}}\right)$, capital goods imports $\left(\mathrm{M}_{\mathrm{C}}\right)$ and industrial production (IP) as independent variables. After setting a regression equation, it is examined whether the variables and the model are meaningful with the help of model statistics, variance inflation factor, normality histogram, residual test. Results showed that the variables and the model are significant.

The stationary of the series was tested with ADF-Unit Root Test, and it is found that the series belong to $\left(\mathrm{M}_{\mathrm{I}}\right),\left(\mathrm{M}_{\mathrm{C}}\right)$, (IP) and (GDP) are stationary at the first difference level I (1). Once all series are stationary at the same level, it is thought that the series could be co-integrated and so a long-term relationship.

The best lag-length was determined as five by the Lag Order Selection Criteria Test before performing Cointegration and VAR Causality Analysis. Johansen cointegration test results indicated a long-run relationship between, capital goods importation, intermediate goods importation, industrial production and economic growth.

To explore the short-term causality and the direction between variables, VAR Granger causality analysis was employed. It is concluded: a) a bidirectional causality between economic growth and intermediate goods importation, b) a bidirectional causality between industrial production and intermediate goods importation, c) a unidirectional causality from industrial production to economic growth, d) a unidirectional causality from capital goods importation to intermediate goods importation, e) there is not any causality between industrial production and capital goods importation as well as economic growth and capital goods importation.

To assess which independent variable explains the variability of the dependent variable over time, Variance decomposition test was employed. As a result of the Variance Decomposition of GDP, while in the first period (quarter) GDP growth is explained by itself at $100 \%$. However In the tenth-period economic growth is explained by $18 \%$ GDP, $18 \%$ capital goods importation, $32 \%$ intermediate goods importation and $32 \%$ industrial production.

The results of the empirical analyses indicate that an increase in capital goods imports and industrial production raise intermediate goods imports, or vice versa. Industrial production and capital goods importation depend on intermediate goods importation. Intermediate goods affect economic growth both directly and indirectly through industrial production.

When the literature is examined, it is seen that the results of the research differ. This is due to the differences in country samples, time zone and the methods used. For example, Bade (2005) and Gerni, C. et al. (2016) concluded in their study that intermediate and capital goods importation influence on economic growth positively. In this study, the 
results showed that capital goods importation does not have an impact on neither economic growth nor industrial production, while intermediate goods importation affects economic growth positively.

Teixeira, A. \& Fortuna, N. (2010) concluded that capital goods imports increases economic growth in their research, while Alam, M. I. (2003) revealed that capital goods importation increases production. In contrast of that, in this study, capital goods importation does not have an impact on neither economic growth nor industrial production.

The results of this research support Miroudot's (2009) conclusion that the importation of intermediate goods has a significant effect on growth.

As a result, the stability of growth both in the short term and in the long term depends on imports of intermediate goods in Turkey. Given the chronic foreign trade deficits of Turkey, this pattern of the economy cause to foreign exchange bottlenecks and could have a negative impact on economic stability. In Turkey, structural transformation is needed to reduce the dependence of economic growth and industrial production on imports of intermediate goods. In this context, the implementation of incentive policies is recommended in order to ensure the production of imported inputs needed in production within the country.

The results of this study also support the claim that liberal policies, which emerged after the 1980s and proposed an export-based growth model, evolved into an import-based growth model in developing countries eventually.

In the following studies, it is recommended to research on a comparative analysis of the effects of imports on shortterm and long-term economic growth and industrial production by considering the level of development of countries. On the other hand, if it is thought that the impact of capital goods importation on economic growth will be delayed, the use of one-period delayed values of the economic growth variable may yield different or more accurate results. That is the why, it is recommended to be used the delayed value of economic growth into the equations system for the analysis that will be taken place for Turkey. 


\section{REFERENCES}

Alam, M. I. (2003). Manufactured Exports, Capital Good Imports, and Economic Growth: Experience of Mexico and Brazil, International Economic Journal, 17:4, 85-105.

Alfaro, L. and Hammel, E. (2007). Capital flows and capital goods, Journal of International Economics 72:128-150.

Awokuse, T. O. (2008). Trade openness and economic growth: is growth export-led or import-led?, Applied Economics, 40:2, 161-173.

Bas, M. and Berthou, A. (2012). The Decision to Import Capital Goods in India: Firms' Financial Factors Matter,, The World Bank Economic Review, 26(3): 486-513.

Bade, M. (2005). The Effect of Imports of Intermediate and Capital Goods on Economic growth in Jordan ( 1980 - 2003), The Hashemite University Faculty of Economic and Administrative Sciences: 1-22. https://eis.hu.edu.jo/deanshipfiles/pub100594269.pdf (26.01.2019)

Chuang, Y. C. (2002). The Trade-Induced Learning Effect on Growth: Cross-Country Evidence, The Journal of Development Studies, 39:2, 137-154.

Eaton, J. and Kortum, S. (2001). Trade in capital goods, European Economic Review, 45 (2001): 1195-1235.

Esfahani, H. S. (1991). Exports, imports, and economic growth in semi-industrialized countries, Journal of Development Economics 35 (1991) 93-116.

Gerni, C. and Değer, M. and Emsen, Ö. and Gencer, A . (2013). Relationship between Import-Led Exports and Economic Growth: The Experience of Turkey (1980-2008). Social Sciences Research Journal, 2 (2): 15-36.

Grossman, G.M. and Helpman, E. (1994). Endogenous Innovation in the Theory of Growth, Journal of Economic Perspectives, 8(1): 23-44.

Kandilov, M. and Leblebicioğlu, A. and Manghnani, R. (2017). Trade Liberalization and Investment in Foreign Capital Goods: $\quad$ Evidence from India, https://editorialexpress.com/cgibin/conference/download.cgi?db_name=MWITC2017\&paper_id=2.

Kasahara, H. and Rodrigue, J. (2007). Does the use of imported intermediates increase productivity? Plant-level evidence, Journal of Development Economics, 87(1): 106-118.

Kim, H. (2017). The Effect of Consumption on Economic Growth in Asia, Journal of Global Economics, 5(3):1-8.

Krauger, A. O. (1983). Trade Strategies, Growth, and Employment, Trade and Employment in Developing Countries, Volume 3: Synthesis and Conclusions, 30-54.

Lawrence, R. Z. and Weınsteın, D. E. (1999). Trade and Growth: Import-Led or Export-Led? Evidence from Japan and Korea, working Paper 7264, Nber Working Paper Series.

Lee, J. W. (1995). Capital Goods Imports and Long-Run Growth Journal of Development Economics, 48(1): 91-110.

Miroudot, S. and Lanz, R. and Ragoussis, A. (2009). Trade in Intermediate Goods and Services, OECD Trade Policy Papers, No. 93, OECD Publishing, Paris.

Mody A. \& Y1lmaz K. (2002). Imported Machinery For Export Competitiveness, The World Bank Economic Review, 16(1): $23-48$.

Sevüktekin, M. \& Çınar, M. (2014). Ekonometrik Zaman Serileri Analizi. Bursa: Dora.

Solow, R. M. (1994) Perspectives on Growth Theory. Journal of Economic Perspectives, 8 (1): 45-54.

Teixeira, A.A.C. \& Fortuna, N. (2010). Human capital, R\&D, trade, and long-run productivity. Testing the technological absorption hypothesis for the Portuguese economy, 1960-2001, Research Policy 39 (2010) 335-350.

Thangavelu, S. M. and Rajaguru. G. (2004) Is there an export or import-led productivity growth in rapidly developing Asian countries? a multivariate VAR analysis, Applied Economics, 36:10, 1083-1093

Türkcan, K. (2007). Outward foreign direct investment and intermediate goods exports, Economie internationale 2007/4 $\left(n^{\circ} 112\right): 51-71$.

Vinnychuk, O. and Grygorkiv, V. and Biloskurski1, R. (2015) The dynamic model of optımal economic Growth in terms of ecological balance:Models construction and results analysis, Verslo sistemos ir ekonomıka busıness systems and economics, 5 (1): 36-45.

Wang, J. and Xu, B. (1999). Capital Goods Trade and R\&D Spillovers in the OECD, Wiley on behalf of the Canadian Economics Association, 32(5): 1258-1274 .

Zhang, X. and Zou, H. (1995). Foreign Technology Imports And Economic Growth In Developing Countries, Policy Research Department, The World Bank, D.C. 20433. 